\title{
G. Mryasaka: A Constitutional and Anthropological Study of Inhabitans of Iwashiro Atami District, Fukushima Prefecture.
}

\section{福島縣岩代熱海住民（郡山地方人)の 体質人類学的研究}

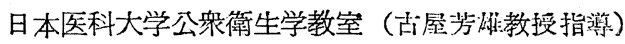

宮坂 五一郎

所謂日本人の体質人類学的地位については 現在まで各研垫者の意向は略一致している。

すなわち大陸地方から渡来したッングース 䒺民種，白人種つUrstamm から分肢して出 て来て東亞に所謂 Rasseninsel を作つている アイヌ民族，また南方から上つて来たインド ネシア, マライ人種等の混血加ら生成せられ たと考えられている．尤も一部の学者はそれ 以外に泪い時代からこの島に定佳していた主 導民族を想定しているか，これを明破に証明 することはむだ出来ない。ただここに明確な ことは上述の上うな多元的な形質は未林だ我か： 国のすべての地域にわたつて本等に渾成され ているものでなく，大都市を除いての山間地 帶, 或いは辺㰻な地方は旧く日本島に渡来し た当時の形質が濃厚に保存せられていること である。例えばアルメニヤ高原には，なおア ルメニア人の旧い型が見当る如く，わが国で もこうした地方が閆々見当るのである.

古屋教授が過去 20 年以上全国各地に於て精 細な人種测定を実施された原因もここにあ る。教授はこれを究明することによつて日本 民族生成の過程を或る程度明らかにしうると 考えているのである．而してそのためには体 質人類学的の比較研究が最も良いと侾えら れ，今日まで昌朴內地の数十地域に於てその 地方型の测定を実施されている。

私かここに瞕島県岩代熱海地方に於てその 住民の体質人類学的調查の成績を発裴するの もその一環としてである。

\section{I 計測条件と項目及び計測法}

この計测の目的は福島県岩代熱海住民の正 確な生体测定を行うことによつて，その地域 住民の特徵を把握することにある。従つて対 像としては，一时寄留及び一見明らかな休質 異状者を除外したことは勿諭，本人が数代さ かのぼつて「地付の出」であることを贋めた 上で，満 20 才以上 50 才未満の成年男子を選 択した。因みにこの地方佳民は近親（地域 冈）結婚の風が强く，测定し得た有効調查数 総計 572 名の殆んと大部分は，その祖先は数 代にととまらず遠い昔からこの地にあつたと 云われるものである。なお本調查では测定地 域が広いために起る必然的な混血傾向を防ぐ ために测定地域を可及的に炏め且つその地域 內の测定該当都はもらさすに测定した。

さて体型比校の基蕉として使用される諸項 目は，体質人類学的価値の高いものをえらん だ。すなわち，R. Martin 著「Lehrbuch der Anthropologie」に従い, Martin 氏の 規蕉に従つて同氏生休計测器を椸い, 次の 25 項目について测定を行つた。

直接测定項目 (12 項目)
(1) 身 長 (2) 耳珠高 (3) 胸骨上㨡高
(4) 肩峰高 (5) 中指尖端高 (6) 肩幅
(7) 頭最大長 (8) 頭最大湢 (9) 最小前頭幅

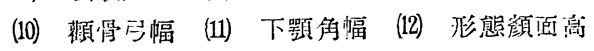
間接测定項目 (2 項目)
(13) 开頭滈 $=$ 身長一正珠宫
(14) 全·上胶長 $=$ 肩峰高一中指尖端高 
比及び指数（11 項目）

(15) 此上肢長 $=\frac{\text { 全上肢長 }}{\text { 身 }} \times 100$

(16) 比秙幅 $=\frac{\text { 肩幅 }}{\text { 身長 }} \times 100$

(17) 比頭長 $=\frac{\text { 䫂最大長 }}{\text { 身 }} \times 100$

(18) 頭長幅指数 $=\frac{\text { 頭最大幅 }}{\text { 頭最大長 }} \times 100$

(19) 頭長耳頭高指数 $=\frac{\text { 耳頭高 }}{\text { 頭最大長 }} \times 100$

（20）頭幅耳頭高指数 $=\frac{\text { 耳頭高 }}{\text { 頭最大幅 }} \times 100$

(21) 頚幅前頚幅指数 $=\frac{\text { 最小前頭幅 }}{\text { 頭最大幅 }} \times 100$

(22) 頭幅顴管弓幅指数 $=\frac{\text { 顴骨弓幅 }}{\text { 頭最大幅 }} \times 100$

(20) 顴骨·幅前頭幅指数 $=\frac{\text { 最小前頭幅 }}{\text { 顧骨弓幅 }} \times 100$

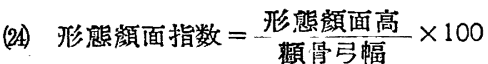

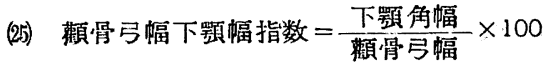

計测器は Stadiometer, Stangenzirkel,

Tasterzirkel, Gleitzirkel を使朋し, 测定票 は古屋教室慣用の身体测定票を用いた，被测 定者はすべて上牛身を裸にし，各項目につい て出来る限り精確に测定した，测定は昭和 30 年4月下旬上り 5 月初旬にかけて行われだ。

本論文に於ける数值取扱法及び計算法は， 古屋，川上両博士の著請に徒つたもので，そ のうち主な記号及び算出法は下記の通りであ る.

(1) 人員数 $\mathrm{N}$ (2) 算術平均 $\mathrm{M}$

$\begin{array}{lll}\text { (3) 標準偏差 } \delta & \text { (4) 変動係数 } \mathrm{V}\end{array}$

(5) $\mathrm{M}$ の平均誤差 $\mathrm{m}$

(6) 型善（T，D.）及びその平均誤差 [m (T.D.)]（古屋教授修正）

T.D. $\pm \mathrm{m}($ T.D. $)=10\left(\frac{1}{\sigma_{1}}+\frac{1}{\sigma_{2}}\right)\left(\mathrm{M}_{1}-\mathrm{M}_{2}\right)$

$$
\pm 10\left(\frac{1}{\sigma_{1}}+\frac{1}{\sigma_{2}}\right) \sqrt{\mathrm{m}_{1}^{2}+\mathrm{m}_{2}^{2}}
$$

（7）不均型等（M.T.D.）及びその平均誤 装 [m(M.T.D)]（古屋教授修正）

M.T.D. $\pm m($ M.T.D. $)=$

$$
\begin{gathered}
\frac{\Sigma\left(\frac{20}{\mathrm{~V}_{1}+\mathrm{V}_{2}}\left(\frac{1}{\sigma_{1}}+\frac{1}{\sigma_{2}}\right)\left(\mathrm{M}_{1} \sim \mathrm{M}_{2}\right)\right)}{\Sigma\left(\frac{2}{\mathrm{~V}_{1}+\mathrm{V}_{2}}\right)} \\
\pm \frac{\Sigma\left(\mathrm{V}_{1}+\mathrm{V}_{2}\left(\frac{1}{\sigma_{1}}+\frac{1}{\sigma_{2}}\right)\left(\sqrt{\mathrm{m}_{1}^{2}+\mathrm{m}_{2}^{2}}\right)\right.}{\Sigma\left(\frac{2}{\mathrm{~V}_{1}+\mathrm{V}_{2}}\right)}
\end{gathered}
$$

\section{II 測定地城概說}

岩代熱敏地方は往時「日高見の国」又は

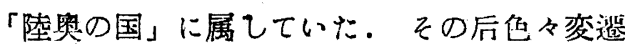
があつたか，明治元年陸奥から分れ，福島県 の所管になつた。

今その概略の位谓を述べれば，福臬県の略 中央に们する娜須火山連峰の一小山間峽地で あつて，四は特に猪苗代湖，盎椅山に接し，

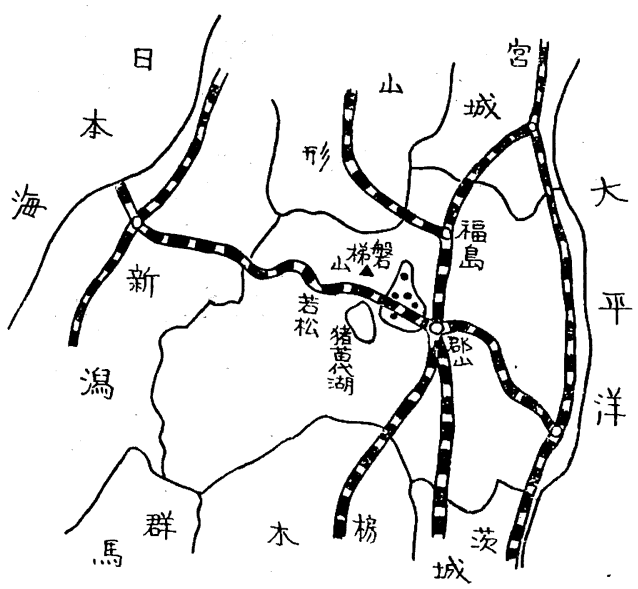

第 1 図岩代熱海地方

北は安達太郎山のふもとをねつて福島及び裏 盤梯地方更に山形県に通し，東は嚾加に開け 郡山本地に連り阿武隈上流を介して阿武隈山 脈を望んでいる。従つて住民の多くは咴燒き を生翡とし，他地方との交通も少なく，代々 近親（地域內）結婚の風が多かつた。

福島県資料集成及び 日本文化史 大系によれ ばこの地方以北には上古蟖帝と称し，繩紋式 石器を使用し，天性强暴で冬は穴居，夏は巢 に住み，狩編漁荻の民として酒泊的生活を続 
け，征南以来容易に王化に染まなかつたと云

了。崇神天皇の朝, 所謂四道将軍の派遭, 斎 明天是の代に阿倍比羅夫をして多賀城に屯田 兵を稙かしめ，內地人を移住させ，更に下つ

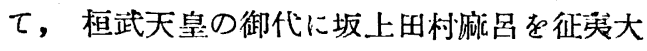
将軍に任じてその鑟定と教化にあたらせ，鎮 守府を多賀城よりはるか北方㗑沢城にまで押 し進めた。以来国家経営か：奥狗地方に進展 し，蝦夷を队地㩐国に移住させ，及るの代り に內地人を奥炣に移して夷地の開発に当らし め，次第に日本民族に同化融合する様にし た.

更に町誌によれば，本町の起源は，碓実な 史料又は根拠とすべき古文㫪はないが，大体 千有余年の古昔にありと云う．特に石筵部落 の真伏野と言う地名処は，往時部民の穴居し た原であつて今尚其の痕跡が所々に政在する。

（因みに真伏と云うのは土を场つて穴を作り 其の上を萱柴等にて蓋い其の中に真伙したを 云う．）即ち此の辺に人民加住居したのは往 古穴居時:代であることば確実であるが如何な る部民が住居したかは明らかでない。

而して町誌に明らかに記せられているは西 曆 1051 年, 源濑義朝命を抨して奥州征伐（前 九年の役)に下向した際，途を本村にとり， その子義家をしてこの地の額取山（安積山） で元服の式を挙げさせたと云う．以来この地 が束夷征代の通路となり（中通りと云う）後 三年の役 (1086) には義家，この地名筵に滞 陣すること三十日，而して賊の動靜を籍い, 目 つ戦捷を同地水上神社に祈り神馬一匹を奉納 したと云う。（其の奉納文及び逪物等は同地 後発氏現に秘藏すると云う．）

由来東国人のこの地に来るもの多く，わけ

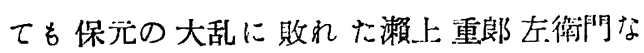
るもの当村に落ち延び部民を統活したと云 う。因みに小字に濑上あり，大字に熱海を初 內上伊豆, 下伊豆, 安子ヶ島等例豆地方の地 名が多い，又猪苗代湖に源を発し阿武隈河上
流に注ぐ五百山の河名性後醍醐天点の御代荻 炬が京都から五百番目の河として名付けたと 云われる。以上の事䠝から洘えれば往時加ら 相当の戸数及び人口があり，北陸地方，束海 地方人との交流も繁しかつた事か：伺がれ る.

以上が瑯土文献による岩代熱海地方の概略 であるか， 本調查は固より，かくの如き伝說 や歷史家の解釈にとらわれることなく，現在 の熱海地方人に就いて客観的科学的测是を行 い，現在の体型の上加らそれが日本民族の人 檑構成に対していかなる地位にあるかを見よ うとしたのである. 勿論現存の形態は必すし も過去のそれでなく，混血その他によつて変 化は起つているが，ただその基礎となるもの は残つて居り，それか;他地方の間の型差とし てあらわれるのである。

\section{1 軀幹四肢に関する調查成精}

身要翰四肢に関する测定成績を一括すれば， 第 1 表の如くなる．以下にその中の身長, 上 肢長, 比上肢長について検討してみる。

1 身 長

身長恪各種の身体测䇥に於て测定世られ， 人種形質の一指標として重んぜられている。 しかし身長はまた，生活環境の如何により変 化することは周知の事実である．即ち栄養。 体育等の種々な複合的な影響により変化す る。しかし乍らこの身長は無限に変化古るの ではなく，その檑族として一是の限界がある ので，そこに人種形質としての価値が生する のである。また身長は他の临計测に比して， 比較的俱测誤差少なく, 变動䋆数も小さく, 大体 3.55 ～ 4.00 を示すこと等を考察すると (本調查では 3.28)。種々の論議はあつても身 長の人種形質としての価值は甚大であると見 なければならない。

岩代熱海地方人の成績は昭和 30 年の测定で 平均值 $159.45 \mathrm{~cm}$ であつた。 
第 1 裴 而畭口四肢の計测偭及び指数值 北 質 $\mathrm{N}$ 岩代熱海地方人 572

$$
\text { 身 }(\mathrm{cm}){ }^{\text {長 }}\left\{\begin{array}{c}
\mathrm{M} \pm \mathrm{m} \\
\sigma \\
\mathrm{V}
\end{array}\right.
$$$$
159.45 \pm 0.22
$$$$
\text { 耳 } \underset{(\mathrm{cm})}{(\mathrm{cm})}\left\{\begin{array}{c}
\mathrm{M} \pm \mathrm{m} \\
\sigma \\
\mathrm{V}
\end{array}\right.
$$$$
5.22
$$$$
3.28
$$

$147.44 \pm 0.26$ 6.01

4.07

\begin{tabular}{|c|c|c|}
\hline \multirow{3}{*}{$\begin{array}{c}\text { 脑骨上橡高 } \\
(\mathrm{cm})\end{array}$} & $\mathrm{M} \pm \mathrm{m}$ & $129.18 \pm 0.20$ \\
\hline & $\sigma$ & 4.87 \\
\hline & V & 3.76 \\
\hline \multirow{3}{*}{ 屑 $(\mathrm{cm})^{\text {嵪 }}$} & $\mathrm{M} \pm \mathrm{m}$ & $130.75 \pm 0.20$ \\
\hline & $\sigma$ & 4.74 \\
\hline & $\mathrm{V}$ & 3.62 \\
\hline \multirow{3}{*}{ 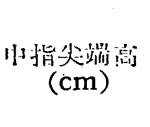 } & $\mathrm{M}_{ \pm \mathrm{m}}$ & $60.44 \pm 0.13$ \\
\hline & $\sigma$ & 3.59 \\
\hline & V & $5.83^{\circ}$ \\
\hline \multirow{3}{*}{$\begin{array}{c}\text { 弪上伎 長 } \\
(\mathrm{cm})\end{array}$} & $\mathrm{M} \pm \mathrm{m}$ & $70.39 \pm 0.13$ \\
\hline & $\sigma$ & 3.15 \\
\hline & V & 4.26 \\
\hline \multirow{3}{*}{ 此上肢長 } & $\mathrm{M} \pm \mathrm{m}$ & $44.22 \pm 0.07$ \\
\hline & $\sigma$ & 1.56 \\
\hline & V & 3.52 \\
\hline \multirow{3}{*}{ 肩 $(\mathrm{cm})^{\text {幅 }}$} & $\mathrm{M}_{ \pm \mathrm{m}}$ & $37.03 \pm 0.07$ \\
\hline & $\sigma$ & 1.81 \\
\hline & V & 4.89 \\
\hline \multirow{3}{*}{ 比，肩 幅 } & $\mathrm{M}_{ \pm}$ & $23.27 \pm 0.05$ \\
\hline & $\sigma$ & 1.10 \\
\hline & V & 4.72 \\
\hline
\end{tabular}

Martin 氏の身長分類に従つて百分率をみ ると第 2 裴の如く「小」が牛数，「中の下」 を玑えて $86.23 \%$ の多きに澾して居る．全体 の分類は加賀山地人と殆んど同じで，炏いで 幣城地方に似ている。他地方との比较に於い て制るように，岩代䓡㵀人はわか：国に於て 治，中身の部に属する。

炏に Mollison 氏型善公式を古屋教授が修 而:した法によつて身長型着を算出し，相互

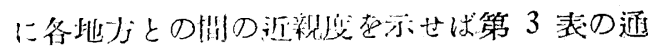
りである。

これによれば身長に於て岩代熱海地方人は
第 2 裴 身長分類裴

分澒過小 小中の下虫小上上 身 長 $130.0150 .0160 .0^{\circ} 164.0167 .01 .70 .0$

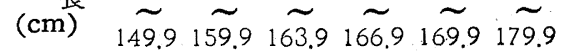

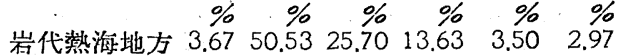
加賀山地 $3.87 \quad 51.11 \quad 27.22 \quad 11.39 \quad 3.89 \quad 2.50$ 土 $\quad \begin{array}{lllllll} & 0.00 & 42.00 & 33.00 & 14.67 & 8.67 & 1.33\end{array}$ 奧 能 登 $5.5252 .14 \quad 23.97 \quad 11.29 \quad 3.96 \quad 3.13$ 落城地方 $1.8948 .67 \quad 24.81 \quad 12.88 \quad 7.21 \quad 4.55$ $\begin{array}{llllllll}\text { 飛 } & \text { 彈 } & 4.11 & 57.78 & 21.92 & 9.96 & 5.11 & 1.12\end{array}$ 加賀平地 $3.01 \quad 44.15 \quad 27.54 \quad 14.40 \quad 7.38 \quad 3.53$ $\begin{array}{lllllll}\text { 越. 蛙 } 3.8860 .00 & 21.66 & 7.77 & 3.88 & 2.77\end{array}$ $\begin{array}{lllllll}\text { 出 需 } 2.35 & 41.88 & 26.36 & 15.61 & 8.24 & 5.56\end{array}$ 三 宅 嶌 $4.00 \quad 32.86 \quad 31.20 \quad 17.60 \quad 8.80 \quad 5.60$ 信州上伊豆 $1.8039 .0028 .8015 .0011 .40 \quad 4.00$

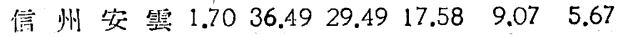

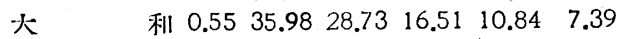
信州做川 1.0033 .5025 .5018 .5015 .006 .50

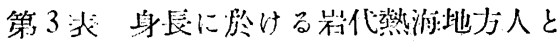
他地了人の型管

\begin{tabular}{|c|c|c|c|c|}
\hline \multicolumn{2}{|l|}{ 各地人 } & $\mathrm{M}_{2}$ & \multicolumn{2}{|c|}{ 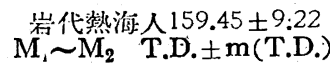 } \\
\hline & 川 & 159.44 & 0.01 & $0.04 \pm 2.16$ \\
\hline 倉 & 舀 & 159.59 & 0.14 & $0.53 \pm 2.03$ \\
\hline 賀山 & 地 & 159.24 & 0.21 & $0.80 \pm 1.35$ \\
\hline 能 登 諵 & 部 & 159.68 & 0.23 & $0.85 \pm 0.96$ \\
\hline & 估 & 159.77 & 0.32 & $1.22 \pm 1.27$ \\
\hline 北海道アイ & 又 & 159.02 & 0.43 & $1.75 \pm 1.75$ \\
\hline 日 & 向 & 158.99 & 0.46 & $1.76 \pm 1.04$ \\
\hline 身 & 海: & 158.96 & 0.49 & .16 \\
\hline 能 & 登 & 158.94 & 0.51 & 1.87 \\
\hline 奄 美大 & 島 & 158.99 & 0.44 & $2.67=$ \\
\hline 整 浙 地 & 方 & 160.17 & 0.72 & 2.7 \\
\hline 飛 & 彈 & $1-8.66$ & 0.79 & $=1.09$ \\
\hline 加 賀 平 & 地 & 160.28 & 0.83 & \pm 0.83 \\
\hline 八 丈 & 藏 & 160.31 & 0.86 & $3.45 \pm 1.31$ \\
\hline 越 & 中 & -158.41 & 1.04 & $3.97 \pm 1.71$ \\
\hline 出 & 雲 & 160.93 & 1.48 & $5.45 \pm 0.97$ \\
\hline 三 宅 & 島 & 161.29 & 1.84 & $6.88 \pm 2.01$ \\
\hline 信州上伊 & 那 & 161.29 & 1.84 & $6.98 \pm 1.38$ \\
\hline 信 州 安 & 盗 & 161.65 & 2.25 & $7.72 \pm 1.22$ \\
\hline 大 & 和 & 161.95 & 2.50 & $9.33 \pm 0.97$ \\
\hline 対 & 婜 & 162.03 & 2.58 & $9.91 \pm 2.17$ \\
\hline 信 州 飯 & 田 & 162.39 & 2.94 & $11.10 \pm 1.66$ \\
\hline 壱 & 岐 & 162.78 & 3.33 & $12.31 \pm 2.86$ \\
\hline 笲 & 球 & 161.96 & 2.51 & $13.49 \pm 2.74$ \\
\hline 北 部 & 州 & 163.20 & 3.75 & $14.51 \pm 1.18$ \\
\hline & 群 & 163.38 & 3.93 & $14.64 \pm 1.04$ \\
\hline
\end{tabular}


白川，艘倉泉，加賀山地，能登南蔀に対して は型美が 1.0 以下で極めて近緗し，北㳙檤つ イヌ，束淤，奥能登，整城地方，打賀平地等 の住民とも比聸的近緗関係にあるに対し，信 州飯田, 壱岐, 琉球, 北部信州, 南朝䰻人に 対しては型羕が 10 以上で比較的近螕度が少な いことが示されている。

\section{2 全上肢長}

全上肢長は肩峰高より中指父端的をひいた

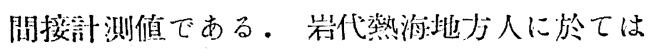
$70.39 \mathrm{~cm}$ であつた。

3 比上肢長

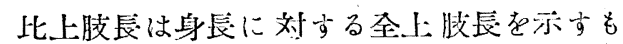
ので，岩代熱海人に於ては，平均值 44.22 で ある、獘城地方人の 44.38 に近い值である。

比上肢長忚他の種々な测定倠に比して变動係 数が小さく，従つて安定性:の大きい值でする ために，相互比校上重慗な数值の一つであ る。

比上肢長の Iwanowski 氏による分糞に従 つて，上肢長の分類を岩代熱游人及びその他

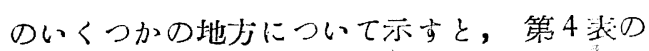

\begin{tabular}{|c|c|c|c|}
\hline \multicolumn{4}{|c|}{ 第 4 裴 上肢分類裴 } \\
\hline 分 類 & 短腕 & 中䏧 & 長腕 \\
\hline 比上肢長 & $\sim 42.9$ & $43.0 \sim 44.9$ & $45.0 \sim$ \\
\hline 岩代熱海地方 & $\begin{array}{r}\% \\
10.88\end{array}$ & $\begin{array}{r}\% \\
51.93\end{array}$ & $\begin{array}{r}\% \\
29.19\end{array}$ \\
\hline 篮城地方 & 17.05 & 51.13 & 31.82 \\
\hline 信州上伊那 & 25.00 & 58.50 & 16.50 \\
\hline 三 宅 島 & 16.00 & 64.80 & 19.20 \\
\hline 八文蔦 & 23.85 & 61.28 & 14.87 \\
\hline 出 雲 & 27.01 & 62.80 & 10.19 \\
\hline 信 州 飯 田 & 35.50 & 58.00 & 6.50 \\
\hline 信 州 安 斅 & 39.32 & 57.09 & 3.59 \\
\hline 大和 & 41.71 & 52.28 & 6.01 \\
\hline
\end{tabular}

通りである。岩代熱海人は中腕が過牛数を占 め, 全体の傾向は盤城地方人に非常に近い。

\section{IV 頭部に関する硎究成績}

頭部に関する種々の計测值及び指数值は人
種相互の近親度を論するのに最も重荘目つ必 荘な価值を有している。唌部に関する 9 項目 の計测值及び指数值 を一括して第 5 裴に示

第 5 泰 頚部の部测值及び指数值，

$$
\text { 形 質 岩代熱激地方人 }
$$

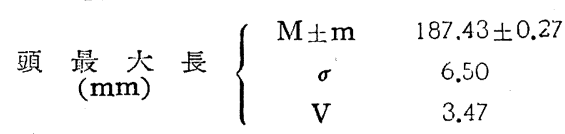

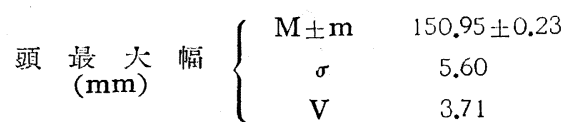$$
\text { 頭長幅指数 }\left\{\begin{array}{cc}
\mathrm{M} \pm \mathrm{m} & 80.86 \pm 0.16 \\
\sigma & 3.88 \\
\mathrm{~V} & 4.81
\end{array}\right.
$$

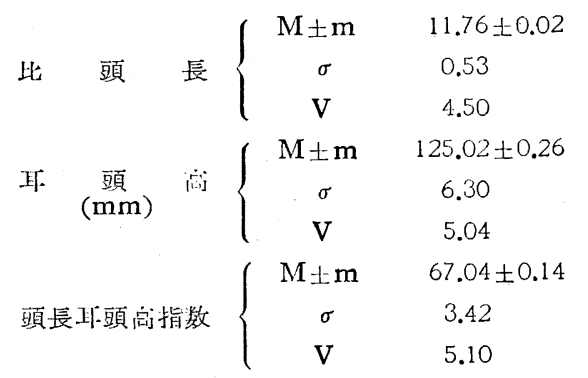$$
\text { 頭幅-正顗湡指数 }\left\{\begin{array}{cc}
\mathrm{M}_{ \pm \mathrm{m}} & 82.54 \pm 0.19 \\
\sigma & 4.53 \\
\mathrm{~V} & 5.49
\end{array}\right.
$$

$$
\begin{array}{r}
\underset{\text { 最小前 頭 幅 }}{(\mathrm{mm})}\left\{\begin{array}{cc}
\mathrm{M} \pm \mathrm{m} & 111.12 \pm 0.19 \\
\sigma & 4.63 \\
\mathrm{~V} & 4.17
\end{array}\right. \\
\text { 頭幅前頭幅指数 } \\
\left\{\begin{array}{cc}
\mathrm{M} \pm \mathrm{m} & 74.21 \pm 0.14 \\
\sigma & 3.26 \\
\mathrm{~V} & 4.39
\end{array}\right.
\end{array}
$$

す.以下この中, 頭最大長, 頭最大幅, 頭長 幅指数, 耳頭高, 頭長耳頭高指数, 頭偳耳顽 高指数について検討してみる.

\section{1. 頭最大長及び頭最大幅.}

頭最大幅灰び頭最大幅は頭型及、び各種の頭 部指数を算出するのに基本となる計测值であ り, 重要なる人種形質としてAnders, Retzius 以来多数の研究者により位用されて来た。本 来頭型を数字で表現すること俳常に因難な 
〔第 22 卷第 4 最

ことである。従つて䫓部の輸䖉を数字にして 表現し，この訓测值及び比.(指数)を求も， 相笛の䭪部の比較をする方法が最を命理的で あり，目つ今のところこれ以上の方法は求め られないと洘えられている。そのためにこ の方法に数分の疑義を示している Boas 氏等 の学派もあるが, 䫓最大長及び䫓最大幅は,

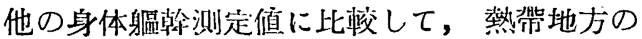
未開人に見られる様な人為的変形を作るもの を除き，後天的な影響をうけること極めて少 なく，且つ骨部のためその测定誤垡の少ない 䚵测值とされている。かくしてその価値に対 する信賴度は低然として極めて高い。

第6 裴 頭最大長に於ける岩代熱海扎力 人を他地方人の型差

\begin{tabular}{|c|c|c|c|c|}
\hline \multicolumn{2}{|l|}{ 各地人 } & \multicolumn{3}{|c|}{ M 岩代熟海地方人 $187.43 \pm 0.27$} \\
\hline 賀 山 & 地 & 187.30 & 0.13 & $0.43 \pm 1.33$ \\
\hline 部 信 & 州 & 187.28 & 0.15 & $0.47 \pm 1.16$ \\
\hline 琉 & 球 & 187.59 & 0.16 & $0.53 \pm 3.16$ \\
\hline 倉 & 島 & 187.60 & 0.17 & $0.55 \pm 1.92$ \\
\hline 宅 & 島 & 187.13 & 0.30 & $0.96 \pm 1.91$ \\
\hline 美 大 & 島 & 187.72 & 0.29 & $0.99 \pm 2.33$ \\
\hline 白 & 川 & 187.80 & 0.37 & $1.15 \pm 2.16$ \\
\hline 州 安 & 舁 & 186.98 & 0.45 & $1.56 \pm 1.21$ \\
\hline 賀 本 & 地 & 188.00 & 0.57 & $1.81 \pm 0.96$ \\
\hline 能 & 登 & 188.10 & 0.67 & $2.22 \pm 1.20$ \\
\hline 飛 & 彈 & 188.30 & 0.87 & $2.86 \pm 1.11$ \\
\hline 土 & 佐 & 188.42 & 0.99 & $3.10 \pm 1.11$ \\
\hline 城 地 & 方 & 188.44 & 1.01 & $3.15 \pm 1.19$ \\
\hline 対 & 馬 & 188.66 & 1.23 & $3.58 \pm 2.21$ \\
\hline 日 & 向 & 188.63 & 1.20 & $3.77 \pm 1.04$ \\
\hline 丈 & 易 & 186.15 & 1.28 & $4.12 \pm 1.30$ \\
\hline 東 & 海: & 185.99 & 1.44 & $4.56 \pm 1.17$ \\
\hline 州上牛 & 那 & 185.67 & 1.76 & $5.56 \pm 1.38$ \\
\hline 朝 & 鮮 & 185.32 & 2.11 & $6.14 \pm 1.03$ \\
\hline 大 & 雬 & 185.06 & 2.37 & $6.99 \pm 0.97$ \\
\hline 登 南 & 部 & 190,20 & 2.77 & $9.06 \pm 1.00$ \\
\hline 州 飯 & 田 & 184.15 & 3.28 & $10.29 \pm 1.62$ \\
\hline 壱 & 岐 & 191.88 & 4.45 & $12 . € O \pm 2.99$ \\
\hline 出 & 雲 & 183.39 & 4.04 & $13.06 \pm 1.00$ \\
\hline 越 & $\Psi$ & 193.70 & $6.2 ?$ & $19.87 \pm 1.64$ \\
\hline 北海道ア1 & 17 & 195.40 & 7.97 & $25.76 \pm 1.72$ \\
\hline
\end{tabular}

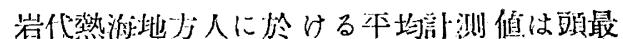
大長 $187.43 \mathrm{~mm}$, 顽最大蕾 $150.95 \mathrm{~mm}$ であつ た.

またこの二つについて各地方との型㯏を郭 算すると第 6 裴，第 7 表の如くである。即ち

第 7 裴 頭最大幅に於ける岩代筫湖地方 人と他地方人の型差

\begin{tabular}{|c|c|c|c|c|}
\hline \multicolumn{2}{|l|}{ 各地人 } & $\mathrm{M}_{2}$ & \multicolumn{2}{|c|}{ 岩代熱海地友人 $150.95 \pm 0.2$} \\
\hline & 中 & 150.92 & 0.03 & $0.11 \pm 1.62$ \\
\hline & 向 & 150.83 & 0.12 & $0.43 \pm 1.03$ \\
\hline 賀 山 & 地 & 150.80 & 0.15 & $0.58 \pm 1.34$ \\
\hline 登 南 & 部 & $150: 70$ & 0.25 & $0.95 \pm 1.00$ \\
\hline & 川 & 150.70 & 0.25 & $0.96 \pm 2.04$ \\
\hline & 佐 & 151.46 & 0.51 & $1.92 \pm 1.24$ \\
\hline . & 球 & 150.26 & 0.69 & $2.52 \pm 3.25$ \\
\hline 能 & 登 & 151.90 & 0.95 & $3.60 \pm 1.04$ \\
\hline 8 & 海: & 149.96 & 0.99 & $3.75 \pm 1.16$ \\
\hline 美 大 & 島 & 149.99 & 1.06 & $3.82 \pm 2.49$ \\
\hline 含 & 島 & 149.90 & 1.05 & $4.00 \pm 1.99$ \\
\hline 出 & 雲 & 152.08 & 1.13 & $4.26 \pm 1.00$ \\
\hline & 彈 & 152,30 & I.35 & $5.20 \pm 1.10$ \\
\hline & 岐 & 152.48 & 1.53 & $5.77 \pm 2.67$ \\
\hline 宅 & 爵 & 152.54 & 1.59 & $6.33 \pm 1.87$ \\
\hline 涐: 道ア1 & 又 & 149.30 & 1.65 & 6.49 上 1.71 \\
\hline 賀 平 & 地 & 149.10 & 1.85 & $7.08 \pm 0.98$ \\
\hline 州上伊 & 那 & 152.96 & 2.01 & $7.61 \pm 1.34$ \\
\hline 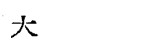 & 和 & 153.11 & 2.16 & $7.69 \pm 0.98$ \\
\hline 城 地 & 方 & 148.90 & 2.05 & $.7 .74 \pm 1.26$ \\
\hline 部 信 & 州 & 153.82 & 2.87 & $10.91 \pm 1.16$ \\
\hline 州 飯 & 田 & 154.45 & 3.50 & $12.73 \pm 1.72$ \\
\hline & 墨 & 154.26 & 3.31 & $13.42 \pm 1.98$ \\
\hline 丈 & 昜 & 154.47 & 3.52 & $13.81 \pm 1.34$ \\
\hline 朝 & 鮮 & 155.41 & 4.46 & $15.68 \pm 1.03$ \\
\hline
\end{tabular}

站最大長に於ては，岩代熱淤人は㺫賀山地，

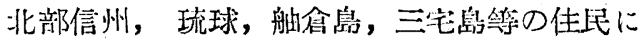
極めて近く，白川，信州安足，才加賀山地，奥 能登，飛彈，土佐，繁城地方住民とを比較的 近緗関係にあるに対し，越中，北海檤アイヌ とは型差 15.0 以上を示して近螕度が極めてう すい。

頭最大幅に於ては岩代熱海: 人蝴越中, 日 
向，加賀山地，能登南部，白川に極 めて近く，士佐，硫球，奥能登，束游: 地方人と比較的近緗関係にあり，对 帛，ハ丈島，南朝鮮とは近親性か;うす い.

\section{2 頭長幅指数}

頭長幅指数は頭最大幅の 頭最大長に 対する百分率で示される指数で，頭型 の簡単な表示法であり，人種の近親度 を示す重要な指標である。岩代熱海人 ではこ.の值は $80.86 \mathrm{~cm}$ で中等型に属 する。 Martin 氏の頭型分類に従つて 分布を調へて見ると第 8 表の通りであ る。

その分布は奥能登, 飛彈, 加賀山地 人に似て居り，中等型に属するものか； 概して多く，長頭型に属するものは少 ないことを示している．全体としての 分布は明らかに中頭型である。次にこ れを型差によつて各地方人と比較して みると第 9 表:の通りである。即ち奥能 登, 飛彈, 東游地力等の佳民 と近親度

第 8 裴 頭長幅指数頭型分類表

頭 型 長頍型中頭型 短頭型過短頭型

\begin{tabular}{|c|c|c|c|c|c|}
\hline \multicolumn{2}{|c|}{ 頍長幅指数 } & $\sim 75.9$ & $\begin{array}{r}76.0 \sim 8 \\
80.9\end{array}$ & $\begin{array}{r}81.0 \sim \\
85.4\end{array}$ & $85.5 \sim$ \\
\hline \multicolumn{2}{|c|}{ 代澇海地方 } & $\begin{array}{r}\% \\
8.92\end{array}$ & $\begin{array}{r}\% \\
45.10\end{array}$ & $\begin{array}{r}\% \\
33.04\end{array}$ & $\begin{array}{r}\% \\
12.94\end{array}$ \\
\hline \multirow[t]{2}{*}{ 能 } & 登 & 5.47 & 49.27 & 39.96 & 5.29 \\
\hline & 彈 & 5.35 & 48.07 & 39.85 & 6.72 \\
\hline \multirow{2}{*}{$\begin{array}{c}\text { 賀 山 } \\
\text { 宅 }\end{array}$} & 地 & 4.78 & 53.09 & 34.83 & 7.30 \\
\hline & 战 & 1.60 & 42.40 & .49 .60 & 6.40 \\
\hline 州 安 & 残 & 0.57 & 43.67 & 48.20 & 7.56 \\
\hline 賀 本 & 地 & 14.81 & .54 .88 & 27.34 & 2.79 \\
\hline 登 南 & 部 & 14.76 & 55.83 & 26.49 & 2.72 \\
\hline \multirow[t]{2}{*}{ 城 地 } & 方 & 18.75 & 54.74 & 22.73 & 3.79 \\
\hline & 利 & 5.25 & 31.38 & 38.82 & 24.30 \\
\hline \multirow[t]{2}{*}{ 州上佋 } & 那 & 2.00 & 31.00 & 48.00 & 19.00 \\
\hline & 露 & 2.14 & 31.64 & 45.84 & 20.38 \\
\hline \multirow[t]{2}{*}{ 丈 } & 島 & 1.79 & 30.00 & 46.67 & 21.54 \\
\hline & 中 & 27.65 & 54.25 & 16.48 & 1.58 \\
\hline 州 领 & 时 & 1.50 & 20.00 & 45.00 & 33.50 \\
\hline
\end{tabular}

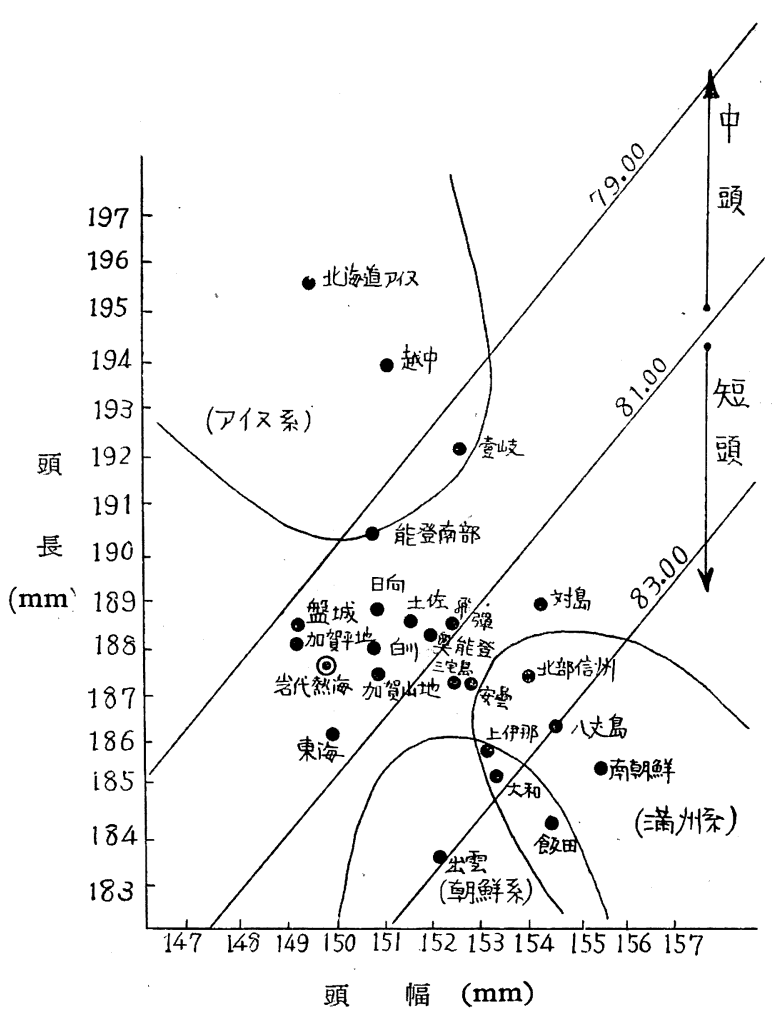

第 2 図頭長幅指数, 頭長, 頭幅の関保図 (註, 図說明後逃)

が極めて强く，加賀山地がこれに次き，南朝 鮮, 越中, 信州飯田, 北海浑アイヌとは近親 度が極めて少ない。

\section{3 耳頭高}

耳頭高の测 定には直 接法と間接法の二つお： あるが，この調查では身長より耳珠高を娍し た間接法により算州した。これによれば，岩 代熱游人では耳 頭高の平均值は $125.02 \mathrm{~cm}$ で 高頭型に属する。

型茎による各地人との比較は第 10 裴の通り で, 対泉, 加賀山地, 飛彈とは近䋑で, 扣 賀本地，然城地方とは比較的近綾であるに対 し，南朝䰻，大和，白川とは極めて近親临か。 少ない。

4 頭長耳䭪滈指数

これは頭最大長に対する耳頚高の比を示す 
第 9 裴，頭長幅指数に於ける岩代熱海地 方人と他地方人の型管

\begin{tabular}{|c|c|c|c|c|c|}
\hline \multicolumn{3}{|c|}{ 务地人 } & \multicolumn{3}{|c|}{ 岩代茭海地方人 $80.86 \pm 0$. } \\
\hline 奥 & 能 & 登。 & 80.83 & 0.03 & $0.174 \pm 1.19$ \\
\hline 飛 & & 彈 & 80.92 & 0.06 & $0.34 \pm 1.12$ \\
\hline 身 & & 潍: & 80.78 & 0.08 & $0.52 \pm 1.38$ \\
\hline 加 & 賀 山 & 地 & 80.59 & 0.27 & $1.56 \pm 1.37$ \\
\hline. \pm & & 傏 & 80.17 & 0.39 & $2.11 \pm 1.23$ \\
\hline 白 & & 川 & 80.42 & 0.44 & $2.37 \pm 2.13$ \\
\hline & 宅 & 䡒 & 81.61 & 0.66 & $4.02 \pm 1.81$ \\
\hline 隽 & 州 宛 & 蔣 & $81 . \subseteq 8$ & 0.72 & $4.62 \pm 1.24$ \\
\hline 日 & & 向 & 79.98 & 0.88 & $4.74 \pm 1.05$ \\
\hline 低 & 美 大 & 菏 & 79.96 & 0.90 & $4.91 \pm 2.40$ \\
\hline 琉 & & 球 & 79.96 & 0.91 & $5.08 \pm 3.14$ \\
\hline 対 & & !!: & 81.85 & 0.99 & $5.92 \pm 1.98$ \\
\hline 艄 & 倉 & $I_{i}$ & 79.89 & 0.97 & $6.16 \pm 1.83$ \\
\hline 壱 & & 㺳 & 79.54 & 1.32 & $6.58 \pm 2.68$ \\
\hline 北 & 部 倍 & 州 & 82.18 & 1.32 & $6.93 \pm 1.14$ \\
\hline חו & 賀 平 & 城 & 79.38 & 1.48 & $8.25 \pm 0.98$ \\
\hline 能 & 登 南 & 部 & 80.83 & 1.50 & $8.49 \pm 1.81$ \\
\hline 大 & & 利 & 82.76 & 1.90 & $9.11 \pm 1.96$ \\
\hline 信 & 州上伊 & 那 & 82.55 & 1.69 & $9.27 \pm 3.00$ \\
\hline 栠 & 城 地 & 方 & 79.04 & 1.82 & $9.64 \pm 1.20$ \\
\hline 出 & & 霔 & 82.67 & 1.81 & $9.69 \pm 0.98$ \\
\hline 公 & 文 & 易 & 82.95 & 2.09 & $10.91 \pm 1.30$ \\
\hline 荫 & 朝 & 熊 & 84.00 & 3.14 & $14.62 \pm 1.02$ \\
\hline 越 & & 中 & 77.92 & 2.94 & $16.32 \pm 1.60$ \\
\hline 信 & & 田 & 84.10 & 3.24 & $16.67 \pm 1.66$ \\
\hline & & & 76.59 & 4.27 & $16.97 \pm 2.66$ \\
\hline
\end{tabular}

もので，岩代熟旅地方に於ては 67.04であつ た。 Saller 氏頭長耳頭高指数による頭型の 分類を示せば第 11 敃:の如くなる．岩代熟海人 は此較的に高頭型が多い，全体の分布として は片雲,信州安等, 飛彈に近い。型差によつて この頭長耳頭高指数を他地方と比较すると第 12 韭の通りになる。これによれば岩代熱游人 は加賀次地，士恢，三宅皇に近く，反対に 南朝䰻, 越中, 北海湴アイヌ, 大和, 白川 とは著るしく近親度がうすい。

5 頭幅耳頭高指数

これは耳頭高の最大幅に対する比である。 岩代熱漏人に於ては82.54である。
第 10 翡 耳頭高に於ける岩代熱海地方 人と他地方人の型差

\begin{tabular}{|c|c|c|c|c|}
\hline \multirow[t]{2}{*}{ 各陫人 } & & $\mathrm{M}_{2}$ & $\mathrm{M}_{1} \sim \mathrm{M}_{2}$ & T.D. $\pm \mathrm{m}(\mathrm{T} . \mathrm{D}$ \\
\hline & 馬 & 152.61 & 0.59 & $1.58 \pm 2.52$ \\
\hline \multirow[t]{2}{*}{ 賀 山 } & 地 & 124.50 & 0.42 & $1.65 \pm 1.34$ \\
\hline & 强 & 125.60 & 0.58 & $1.65 \pm 1.09$ \\
\hline 宅 & 島 & 125.68 & 0.66 & $1.80 \pm 2.24$ \\
\hline 道ア & 又 & 125.70 & 0.68 & $2.10 \pm 1.90$ \\
\hline \multirow{2}{*}{$\begin{array}{l}\text { 部 } \\
\text { 信 } \\
\text { 資 斥 }\end{array}$} & 州 & 124.22 & 0.80 & $2.31 \pm 1.17$ \\
\hline & 地 & 125.80 & 0.78 & $2.51 \pm 0.95$ \\
\hline \multirow[t]{4}{*}{ 州上佊 } & 那 & 126.37 & 1.35 & $4.13 \pm 1.39$ \\
\hline & 住 & 126.65 & 1.63 & $4.50 \pm 1.32$ \\
\hline & 需 & 126.71 & 1.69 & $4.98 \pm 0.92$ \\
\hline & 小 & 123.41 & 1.61 & $5.05 \pm 1.71$ \\
\hline 州 安 & 量 & 126.98 & 1.96 & $5.25 \pm 1.28$ \\
\hline \multirow{3}{*}{$\begin{array}{ll}\text { 城 地 } \\
\text { 登 觕 }\end{array}$} & 为 & 122.52 & 2.50 & $6.08 \pm 1.41$ \\
\hline & 部 & 123.20 & 1.82 & $6.25 \pm 1.11$ \\
\hline & 海: & 127.57 & 2.55 & $6.72 \pm 1.24$ \\
\hline \multirow{4}{*}{$\begin{array}{c}\text { 州 领 } \\
\text { 丈 }\end{array}$} & 向 & 127.42 & 2.40 & $7.33 \pm 1.00$ \\
\hline & 田 & 127.68 & 2.66 & $7.76 \pm 1.72$ \\
\hline & 島 & 128.11 & 3.09 & $8.80 \pm 0.87$ \\
\hline & 岐 & 128.61 & 3.59 & $10.36 \pm 0.30$ \\
\hline \multirow[t]{2}{*}{ 美 大 } & 島 & 128.37 & 3.35 & $10.86 \pm 1.40$ \\
\hline & 球 & 129.13 & 4.11 & $11.56 \pm 3.69$ \\
\hline 朝 & 蘚 & 129.39 & 4.34 & $13.32 \pm 1.03$ \\
\hline \multirow[t]{3}{*}{ 能 } & 登 & 120.60 & 4.42 & $14.56 \pm 1.19$ \\
\hline & 利 & 130.91 & 5.89 & $16.12 \pm 0.95$ \\
\hline & 川 & 117.80 & 7.22 & $21.70 \pm 2.24$ \\
\hline 倉 & 島 & 115.90 & 9.12 & $24.56 \pm 2.41$ \\
\hline
\end{tabular}

第 11 裴 頭長耳頭高指数分類表

\begin{tabular}{|c|c|c|c|c|}
\hline 頭 & 步 & 低頭型 & 中頭型 & 高頭型 \\
\hline 頍長耳-頭滈打 & 旨数 & $\sim 57.9$ & $58.0 \sim 62.9$ & $63.0 \sim$ \\
\hline & & $\%$ & $\%$ & $\%$ \\
\hline 代偝海城 & 方 & 0.52 & 12.43 & 87.05 \\
\hline & 雲: & 0.87 & 11.80 & 87.33 \\
\hline 州 妄 & 量 & 1.32 & 14.18 & 84.50 \\
\hline & 彈 & 2.37 & 16.06 & 81.57 \\
\hline 宅 & 萿 & 2.40 & 17.60 & 80.00 \\
\hline 州上伊 & 那 & 0.00 & 8.00 & 92.00 \\
\hline 州 领 & 터 & 0.00 & 9.50 & 90.50 \\
\hline 丈 & 蛙 & 1.54 & 7.59 & 90.51 \\
\hline 城 地 & 方 & 13.26 & 24.05 & 62.69 \\
\hline & 中 & 3.79 & 32.40 & 64.81 \\
\hline & 和 & 0.49 & 2.21 & 97.30 \\
\hline
\end{tabular}




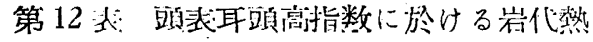
旅地方人を他地方人の型等

\begin{tabular}{|c|c|c|c|c|}
\hline \multicolumn{2}{|l|}{ 各地 人 } & \multirow{2}{*}{$\begin{array}{l}M_{2} \\
67.02\end{array}$} & \multicolumn{2}{|c|}{$\begin{array}{l}\text { 岩代熟湤人 } 67.04 \pm 0.14 \\
\mathrm{M}_{1} \sim \mathrm{M}_{2} \quad \text { T.D. } \pm \mathrm{m} \text { (T.D. }\end{array}$} \\
\hline 加 賀 平 & 地 & & 0.02 & $0.12 \pm 0.94$ \\
\hline \pm & 佐 & 67.12 & 0.08 & $0.40 \pm 1.31$ \\
\hline 宅. & $\varphi^{\varphi_{j}}$ & 66.89 & 0.15 & $0.75 \pm 2.27$ \\
\hline 䧺 & 彈 & 66.76 & 0.28 & $1.47 \pm 1.28$ \\
\hline 賀 山 & 地 & 66.56 & 0.48 & $2.72 \pm 1.34$ \\
\hline 対 & 宫 & 66.49 & 0.55 & $2.73 \pm 2.48$ \\
\hline 壱 & 岐 & 67.69 & 0.65 & $3.59 \pm 2.92$ \\
\hline 部 信 & 州 & 66.30 & 0.74 & $3.84 \pm 1.19$ \\
\hline 日 & 向 & 67.78 & 0.74 & $4.19 \pm 1.00$ \\
\hline 州＼cjkstart安 & 悬 & 68.06 & 1.02 & $4.94 \pm 1.30$ \\
\hline 信 州上伊 & 那 & 68.09 & 1.05 & $5.91 \pm 1.04$ \\
\hline 奄 美 大 & $\varphi^{\prime}$ & 68.25 & 1.21 & $6.79 \pm 2.59$ \\
\hline 架 & 㴰 & 68.67 & 1.63 & $8.03 \pm 1.20$ \\
\hline 丈 & $\varphi^{\prime}$ & 68.76 & 1.72 & $8.79 . \pm 1.37$ \\
\hline 找 地 & 方 & 64.82 & 2.22 & $9.99 \pm 2.04$ \\
\hline 登 南 & 部 & 65.44 & 1.60 & $10.23 \pm 1.00$ \\
\hline 筑 & 球 & 69.17 & 2.13 & $11.03 \pm 3.75$ \\
\hline 出 & 管 & 69.20 & 2.16 & $11.53 \pm 0.77$ \\
\hline 州 饭 & 田 & 69.53 & 2.49 & $13.21 \pm 1.76$ \\
\hline 能 & 登 & 64.64 & 2.40 & $14.49 \pm 1.1 .9$ \\
\hline 朝 & 鮮 & 69.86 & 2.82 & $15.17 \pm 1.03$ \\
\hline 越 & 中 & 64.29 & 2.75 & $15.62 \pm 1.73$ \\
\hline 北游道ア1 & 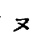 & 64.18 & 2.86 & $15.87 \pm 1.93$ \\
\hline 火 & 利 & 71.06 & 4.02 & $19.17 \pm 0.94$ \\
\hline 香 & 川 & 62.75 & 4.29 & $22.39 \pm 2.36$ \\
\hline
\end{tabular}

第 13 裴 頭幅耳頭高指数頭型分類裴

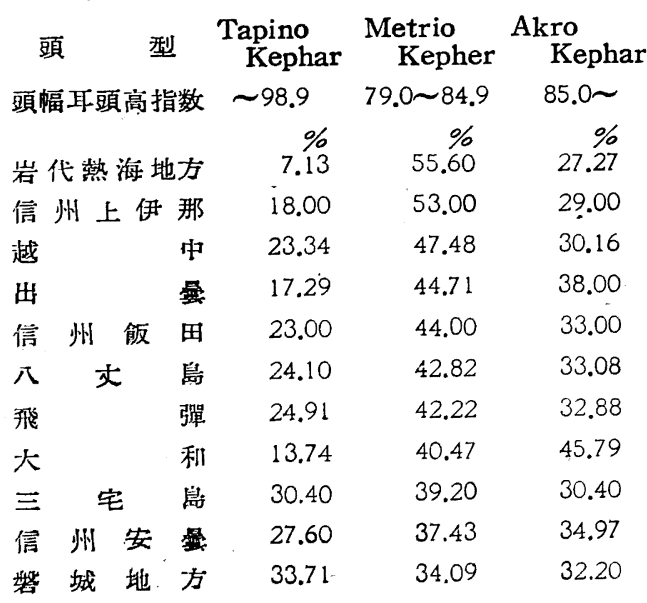

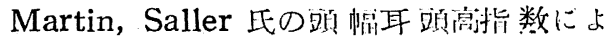
る頭型分類を示せば第 13 紧の如くである。全 体の分行としては，信州上俳那人に比校的近 い分布であり，中頭型が過斗数を占めてい

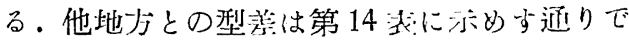

第 14 裴 顽幅耳顽高指数に於ける岩代䇾 㴰地方人と他地方人の型管

各地人

㞸代熟晸地方人 $82.54 \pm 0.19$

\begin{tabular}{|c|c|c|c|c|}
\hline & & $\mathrm{M}_{2}$ & $\mathrm{M}_{1} \sim \mathrm{M}_{2}$ & T.D. $\pm \mathrm{m}$ (T.D \\
\hline 78 & 彈 & 82.56 & 0.02 & $0.08 \pm 1.10$ \\
\hline 賀 山 & 地 & 82.56 & 0.02 & $0.08 \pm 1.29$ \\
\hline 言州上伊 & 那 & 82.62 & 0.08 & $0.35 \pm 1.37$ \\
\hline 论 登 南 & 部 & 82.46 & 0.08 & $0.39 \pm 1.04$ \\
\hline 杫 & 中 & 82.44 & 0.10 & $0.43 \pm 1.77$ \\
\hline 丈 & 喤 & 82.98 & 0.44 & $1.77 \pm 1.36$ \\
\hline 州 饭 & 田 & 83.01 & 0.47 & $1.96 \pm 1.69$ \\
\hline 宅 & 矊 & 82.00 & 0.54 & $2.14 \pm 2.16$ \\
\hline 城 地 & 方 & 81.84 & 0.70 & $2.44 \pm 0.53$ \\
\hline 朝 & 鮮 & 83.34 & 0.80 & $3.38 \pm 1.05$ \\
\hline 出 & 曇 & 83.55 & 1.01 & $4.25 \pm 0.97$ \\
\hline 対 & 馬 & 81.42 & 1.12 & $4.42 \pm 2.37$ \\
\hline 土 & 佐 & 83.76 & 1.22 & $4.95 \pm 1.32$ \\
\hline 北㳙道ア1 & $x$ & 83.93 & 1.39 & $5.81 \pm 1.93$ \\
\hline 北 部 信 & 州 & 80.72 & 1.82 & 7.53 上 1.17 \\
\hline 信 州 安 & 叠 & 84.49 & 1.95 & $7.30 \pm 1.27$ \\
\hline 壱 & 岐 & 84.54 & 2.00 & $8.91 \pm 2.80$ \\
\hline 加 賀 平 & 地 & 84.48 & 1.94 & $8.98 \pm 0.91$ \\
\hline 日 & 向 & 84.67 & 2.13 & $9.22 \pm 1.02$ \\
\hline 大 & 利 & 85.05 & 2.51 & $9.66 \pm 0.97$ \\
\hline 果 & 海 & 85.23 & 2.69 & $10.19 \pm 1.22$ \\
\hline 能 & 登 & 80.04 & 2.50 & $11.39 \pm 1.19$ \\
\hline 美 大 & 島 & 85.56 & 3.02 & $1272 \pm 2.61$ \\
\hline 琉 & 球 & 86.04 & 3.50 & $14.01 \pm 3.50$ \\
\hline & 川 & 78.27 & 4.27 & $18.15 \pm 2.31$ \\
\hline
\end{tabular}

ある。東海, 飛彈, 加賀山地, 能登南蔀人に 極めて近く，琉球，白川人とは遠線である。

\section{V 頋面に関する研究成績}

顏に関する测定は，身翰，四肢及び頭に於 ける誻計测並びに指数と洪に人程比㙂上極め て重要な指標をなしている。この顏面を示め 方計测值，指数值を先す一括して第 15 裴にし 


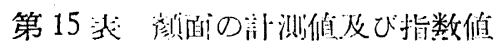

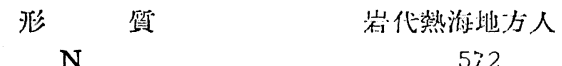

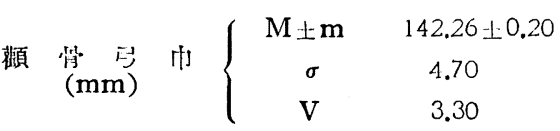

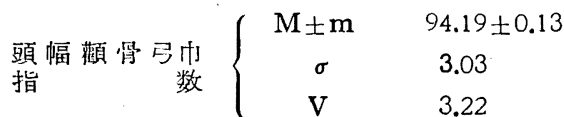

頼骨弓幅前頭幅
指 数 $\left\{\begin{array}{cc}\mathrm{M} \pm \mathrm{m} & 78.72 \pm 0.09 \\ \sigma & 2.04 \\ \mathrm{~V} & 2.59\end{array}\right.$

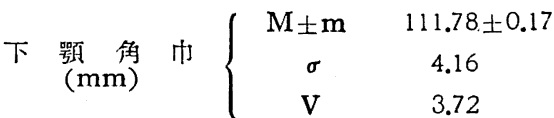

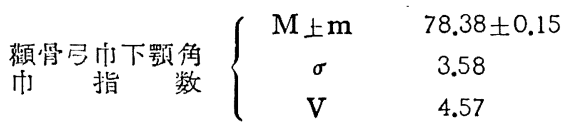

形熊 顔 面 演 $\left\{\begin{array}{cc}\mathrm{M} \pm \mathrm{m} & 123.07 \pm 0.18 \\ \boldsymbol{\sigma} & 4.37 \\ \mathrm{~V} & 3.55\end{array}\right.$

班態頑面指数 $\left\{\begin{array}{cc}\mathrm{M} \pm \mathrm{m} & 86.72 \pm 0.13 \\ \sigma & 3.06 \\ \mathrm{~V} & 3.53\end{array}\right.$

めす。

1 顴骨局幅

顴骨弓幅は最小前頭幅，下顎伨幅と基に顏 面の檟径を示す三重要計测值として，Kretschmer, Sigaud, Kruse 氏の体型分類に附 随しての顏圙分類に重姴な役割を示しており， しばしば蒯いられる测定值である。これにつ いて部测值とそれに伴う比率を求め，それら について教意するならば一層の価值を有する ものとなる。更に顴骨弓幅は環境及び外的因 子の影響を覀けることも僅少であり，遺伝的 関系を高度に示すものとされている。変動係

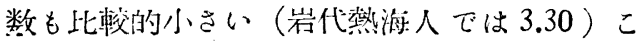
とはこの值の安定性在を亦占。

岩代熟游人に於ける 测定成績は $142.26 \mathrm{~mm}$ でありこの值は奧能登人に近い。

2 頭幅顴骨弓幅指数

代指数は顴骨・幅の頭最大幅に対する比で

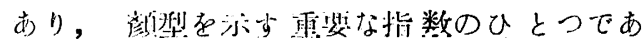
る。岩代熱游人に於てはこ，の指数は 94.19 であつた。

\section{3 下鄂页保幅}

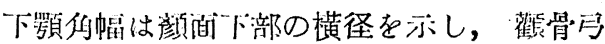
幅と共に顏面分類上重荘䀠されている。

Sigaud 氏の体型分類では渻化器 型及び脳 型を，この下顎何幅の大小によりピラえッド 型及び逆ピラえッド型として判定に利朋して いる，岩代熱泭人に於ては $111.78 \mathrm{~mm}$ であつ た。

\section{4 颧骨弓幅下顎伯幅指数}

本指数はもつともしばしば沜型分類に使用 される．顏中央部以下の顔型の広，狹が示さ れるので颜型研笢上欠くべからざるものとさ れている。岩代熱海人の成績は78.38であつ て中等型に属している。

Landburg-Linders 疋び Saller 氏の顏型 分類法在朋いて，分類すると第 16 裴の如くで

第 16 裴 顧骨弓下顎伯幅指数顏型分類裴

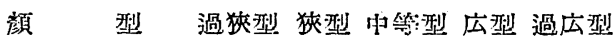

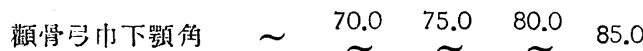

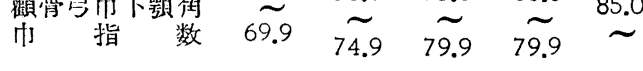

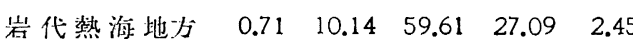

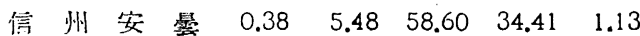
信，州秥田 $0.50 \quad 15.00 \quad 57.50 \quad 25.00 \quad 2.00$ $\begin{array}{llllll}\text { 越的 } 1.07 & 18.27 & 56.45 & 23.65 & 0.53\end{array}$ 然城地方 $1.14 \quad 14.21 \quad 52.27 \quad 26.51 \quad 5.81$

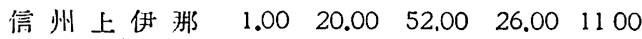

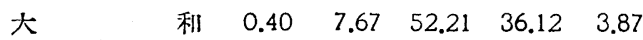

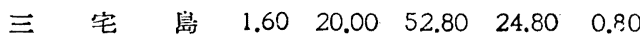
$\begin{array}{llllllll}\text { 飛 } & \text { 彈 } & 1.49 & 26.03 & 51.18 & 20.42 & 0.87\end{array}$ 八 公 $\begin{array}{llllll}\text { 㟢 } & 2.57 & 27.18 & 51.02 & 18.46 & 0.77\end{array}$ $\begin{array}{lllllll}\text { 出 } & \text { 晴 } & 0.60 & 22.72 & 60.72 & 15.01 & 0.94\end{array}$ ある。即古岩代熱海人に於ては，中等型，広 型を合せると全体の $87.60 \%$ を占め，中等型 が一番多く，炏いで広型，狄型となつてい る。

5. 形態顏面湻 


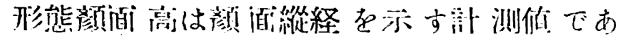

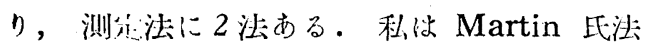
により， Nasion と Gnathion との投射高 を测定した。（他法は Nasion の代りに耳根 最四部を䏳いるものである。）その成績は $123.07 \mathrm{~mm}$ であつた。

\section{6. 形態颜面指数}

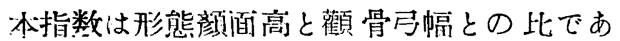

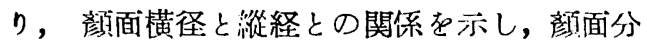
颣上重要である。本地方に於ての成績は, 86.72 であつた．形態顏面指数によつて颜型の 分類をすると第 17 裴の如くである. 即ち岩代

第 17 裴 形態顏面指数颜型分類表

钼型過広型広型中等型狹型過狭型

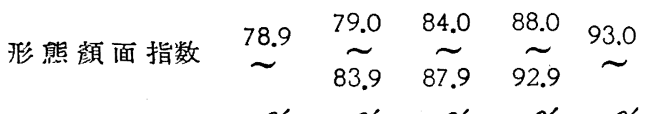
岩代繁海地方 $\quad \begin{array}{rrrrr}1.75 & 15.03 & 49.29 & 32.89 & 1.07\end{array}$ 盤 城地 方 $4.36 \quad 23.48 \quad 28.60 \quad 30.87 \quad 12.69$ $\begin{array}{llllllll}\text { 八 } & \text { 丈 } & \text { 島 } & 1.28 & 22.56 & 36.67 & 29.23 & 10.23\end{array}$ $\begin{array}{lllllll}\text { 出 } & \text { 露 } & 4.36 & 26.01 & 33.58 & 28.21 & 7.84\end{array}$ 三 宅 嶌 $\begin{array}{lllllll}640 & 26.40 & 30.40 & 30.40 & 6.40\end{array}$ $\begin{array}{lllllll}\text { 越 中 } & 8.66 & 29.03 & 31.72 & 24.19 & 6.98\end{array}$

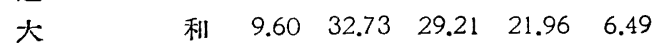
信州 飯 田 $10.00 \quad 29.00 \quad 33.50 \quad 22.00 \quad 5.50$

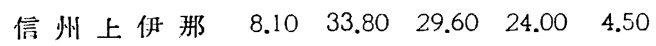
$\begin{array}{lllllll}\text { 信 州 安 暴 } 12.85 & 40.08 & 28.17 & 15.31 & 3.59\end{array}$

䰻激地方人は他地方にくらべて中等型少ほと んどで牛数を占め, 過広型及び過狄型は特に 少なく，全般の分布は出雲，八丈島，憋城地 方に似ている。

型差によつてこの指数による他地方との比 較を示せば第 18 裴:の如くである.土佐, 出雲 に近く, 盤城地方, 加賀山地, 東海, 加賀本 地とも比较的近く, 信州安暴, 白川, 飛彈と は遠緣である。

\section{VI 平均型差による總合比較法}

本調查に於ては各人種間の近䋎関係の度合 を亦すのに型管及び本均型养の方法を使肪し
第 18 裴 形態剂面指数に於ける岩代熱海: 地方人と他地方人の型哆

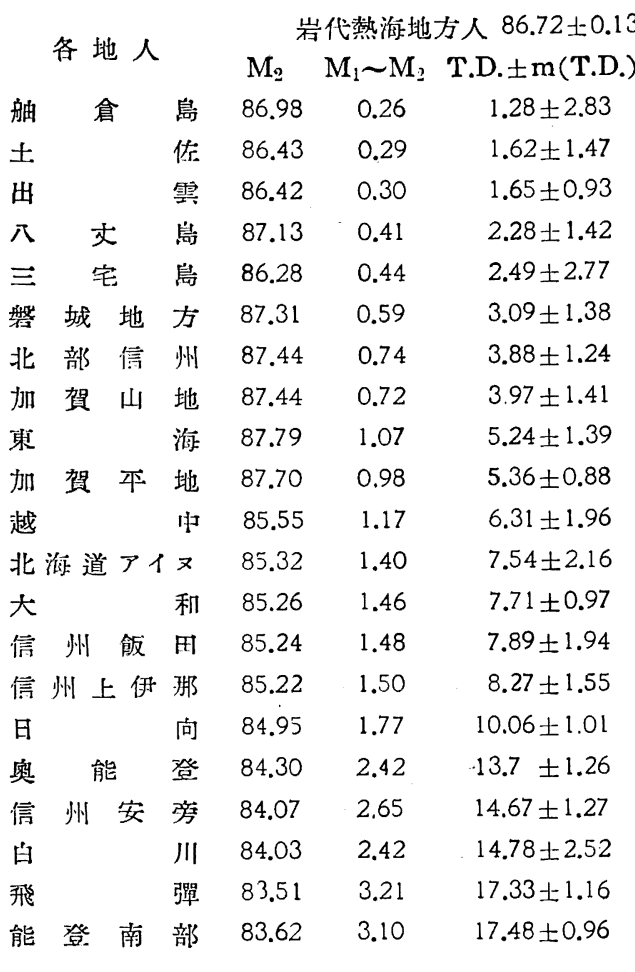

た。従来人種的識别には差の有意性

$\left(\frac{M_{1} \sim M_{2}}{V m^{2}+m_{2}^{2}}\right)$ 多数の計测項目, 指数項目 について訃算し，これを本均してその近似度 を判定しょうとした。

Pearson 氏の㮴矤類似係数及びドイッ人颣 学派の鿷好している Mollison, Poniatowsky 氏の型差の方法等か;朋いられたか，現在最も 使用されている方法は種族型差である。型美 は当初䋆数 50 として Mollison氏により洔 察されたか，Poniatowsky 氏は便宣上係数 を 100 に修正した。

占屋教授は更に係然を 10 とされ，II の計测 法の項で係した Typendiffereuz (T.D.) の 方法に修正された。平均型荠も局様に古屋教 授は，守へての項目の型养を同価值に取技う ことを不可とし，それぞれの変動係数 (V) 
第 19 裴 平均型洁の岩代熱海地方人と 他地方人との比恔

\begin{tabular}{|c|c|c|}
\hline 各㘩人 & \multicolumn{2}{|c|}{ 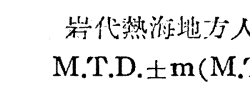 } \\
\hline 賀 怆 & 地 & $1.41 \pm 1.35$ \\
\hline & 佮 & $2.29 \pm 1.23$ \\
\hline 宅 & $r_{j}$ & $3.51 \pm 2.15$ \\
\hline & 媹. & $4.16 \pm 1.14$ \\
\hline 賀 平 & 地 & $4.38 \pm 0.86$ \\
\hline & 淮 & $4.44 \pm 1.20$ \\
\hline 倉 & 嶌 & $4.74 \pm 2.11$ \\
\hline 城 地 & 方 & $5.11 \pm 1.27$ \\
\hline 能 & 登 & $5.32 t 1.15$ \\
\hline & 向 & $5.40 \pm 1.03$ \\
\hline 美 大 & 島 & $5.45 \pm 2.28$ \\
\hline 丈 & 鼠 & $5.56 \pm 1.30$ \\
\hline 州上伊 & 那 & $6.06 \pm 2.18$ \\
\hline 州 安 & 量 & $6.52 \pm 1.20$ \\
\hline 部 篗 & 州 & $6.54 \pm 1.16$ \\
\hline & 婜 & $6.82 \pm 2.23$ \\
\hline 登 南 & 部 & $7.29 \pm 1.21$ \\
\hline & 雪 & $7.86 \pm 0.94$ \\
\hline & 球 & $7.94 \pm 3.38$ \\
\hline & 川 & $8.06 \pm 2.19$ \\
\hline & 凹 & $8.52 \pm 1.72$ \\
\hline & 汥 & $8.84 \pm 1.31$ \\
\hline & 利 & $10.06 \pm 1.07$ \\
\hline 州 领 & 用 & $10.60 \pm 1.73$ \\
\hline & & $10.67 \pm 1.96$ \\
\hline 朝 & 群 & $12.03 \pm 0.93$ \\
\hline
\end{tabular}

の逆数 $\left(\frac{1}{\mathrm{~V}}\right)$ により重みづけを行い， その上で什均するう法をとられた。こ れは例えば頭長幅指数の如き测 定誤差 も比較的少なく，従つて变動係数少; 嚾 に 3 J至 4 というが如き安定した人種 形質としても価值の大きい测度を，他 の例えば鼻指数の如き变型係数の 30 以 上にも達するものと同列同価值に取扱 うことの不命理を洘虑せられたためで ある。この修正された型着及び本均型 美の算出方法によつて阧治されたもの が第19裴である。またこれを図示する
と第 3 図の如くなる．この場合本均型恙は， 身長，頭最大長，頭最大幅，頭長幅指数，耳 頭高，頭長耳頭高指数，頭幅耳顽高指数， 形態顈面指数の代裴的 8 項目だけについて算 州した。

各地人との本均刑登 7.9 .以下のものは江親

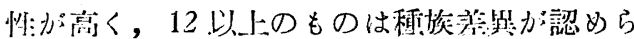
れるものとして検討すると，岩代熱激地方人 は，加賀山地，土伎，三宅島，飛彈，加賀平 地，東㳙等の佳民とは特に近緣性:が高く，炏 いで盤城地方，奥能登に近く，大和，信州微

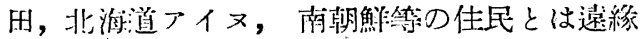
であることがわかつた。これは本地方が往占 「ェン゙地」と称された地域の最南端に大体一 致し，当時西方加ら押寄せて来た人種か：国家 経営の上からそその后長く士着した訓をとして 興味深いことである。次にさきの 8 項目の各

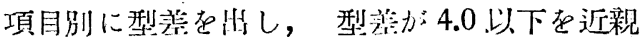
度高く，15.0以下を近哾度の認められないも のとして，これを一筧裴にすると第20裴の通 りである。これによれば 4 項目以上に於て型

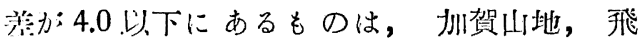

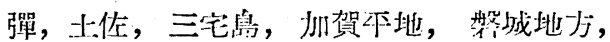
奥能登，北部信州，白川であり，3 項目以上

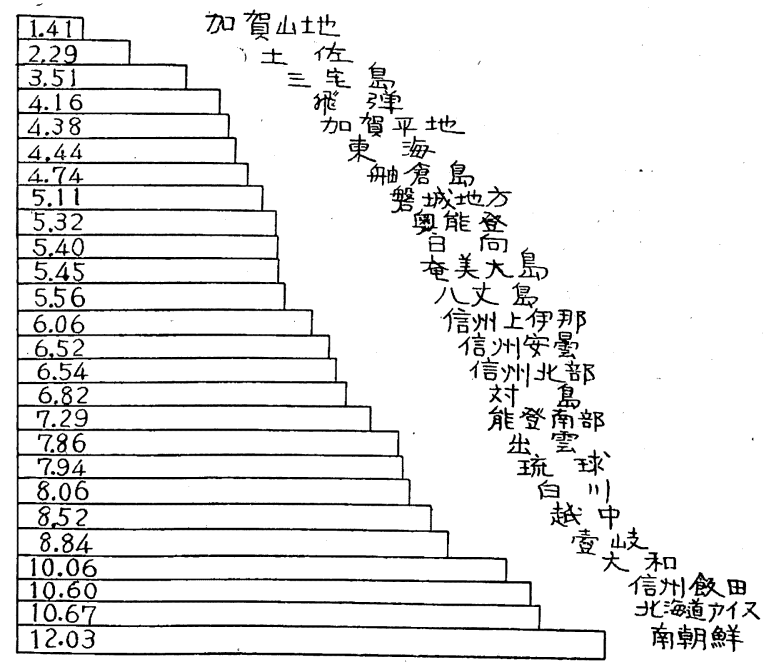

第 3 図岩代熱淤地方人一各地人平均型差 
第 20 表 岩代熱海地方人と各地方人との各項目の近親度一覺表

形質

型差 4.0 以下

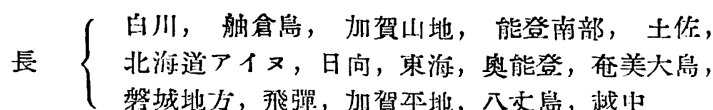

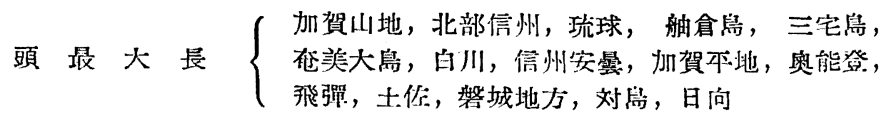

頭最大幅 $\{$ 越中, 日向, 㧈賀山地, 能登献部, 白川, 上仵,

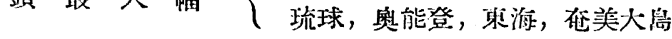

頭長幅 指数 \{ 感能登, 飛彈, 身海, 加賀山地, 土佐, 白川

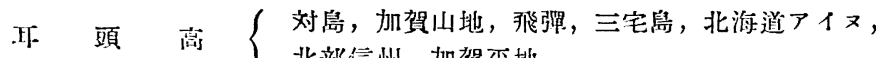

北部信州, 加賀不地

頭長耳頭高指数 （加賀斥地，土佐，三宅島，飛彈，加賀山地， \{対島, 壱岐, 北部傍州

頭幅耳頭宫指数

形態顔面指数

計

$\{$ 死彈, 加賀山地, 信州上伊那, 能登南部, 越中,

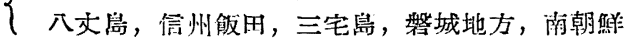

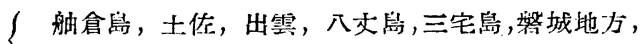
北部信州, 加賀山地

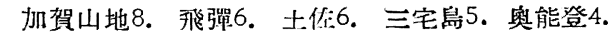
暂城4. 加賀平地4. 白川4. 北部信州4. 東海:3. 能登南部3, 越中3. 艘倉島3. 奄美大島3. 日向3. 八丈岛3. 対岛3. 北海道アイ邓2. 琉 球2. 信州安最1. 上伊那1。饭田 1 . 壱岐1, 出零1。 南朝鮮1。
型差15.0以上

$\%$

ᄂ

越川，北海羊アイ邓

南朝然

越小，㑑州敛田， 北游道アイ邓

大秃，白川，舳倉島

㣮朝䇒，越山，北海道 アイヌ, 大利, 白川

白川

飛彈, 能登南部

越中3. 北海道アイヌ3. 白川3. 南朝鮮2. 大和 2 . 信州饭田 1 . 舳倉島 1 . 飛彈1. 能登南部1

棓 17
に於て型美か：15.0以上にあるものは越中，北 海檤フイヌ，白川人となっている。

\section{VII 偏差折線による比較}

平均型差による比较法は多数の種族との近 親度を一数值で一目膫然に比较観察されてい る. 故にこの欠点を裐うために Mollison 氏 の偏差折湶図法にょり検討した。これには偏 美曲線法 $\frac{M_{1} \sim M_{2}}{\sigma_{1}}$, 偏曾比曲線法 $\frac{M_{1} \sim M_{2}}{m_{1}}$, 型筷曲湶法 $10\left(\mathrm{M}_{1} \sim \mathrm{M}_{2}\right)\left(\frac{1}{\sigma_{1}}+\frac{1}{\sigma_{2}}\right)$ の 3 種の方法があるが，うち型差曲線法は基礎種 族と被比較種族とが互に変更しても正負の方 问方朔となるだけで絕対值は変らす，其線に 対して対称的な曲湶を满くため応用も広いの てここれを游い，岩代熱游人と各地人との比较
を試みた。比較の対称としては加賀山地，來 海，盤城地方，大和，北㴰檤アイヌの5つを 取つた。

これを第4図によつてみれば明らかな如 く, 大和, 出雲等の広頭型人種とは谌た親近 度少なきこと，東海，舟城地方とは近緣関係 にあり，加賀山地人に対して罚だ近親度が强 いことが示されている。

\section{VIII指数関係図示法による比較}

人種近親度を比較する皆合各部测值，重望 であるか，これらょり算比される指䉼值はよ り重要である。しかし指数值のみではその構 成分子がはつきりせす，指数值の差加如何に して生じたかを非明しないこの弱点を除く ため指数值とその 样成分子との相互関係を図 示することにより比较倹討 占る方法小䏳いら 


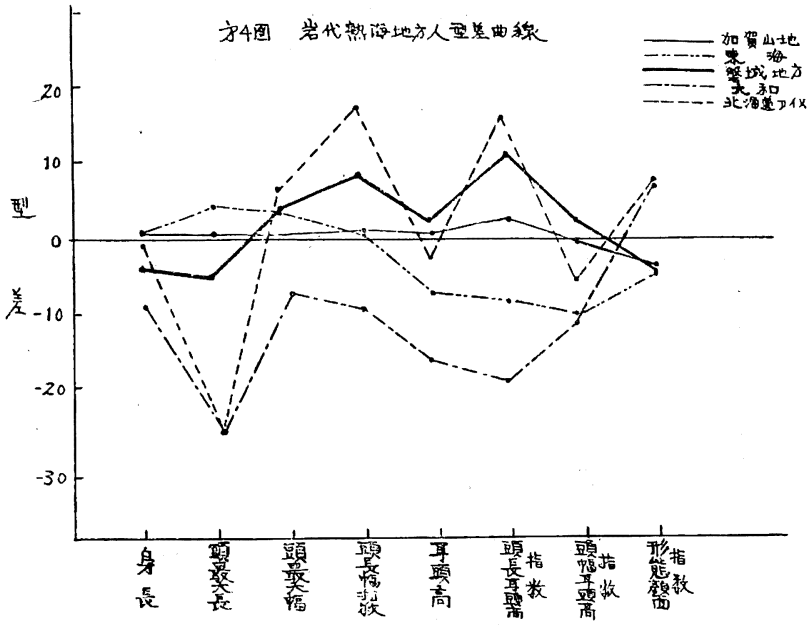

第 4 図 岩代鶖海地方人型差曲線

れている。これは今村，熊沢両氏により朝

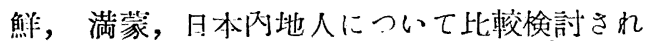
た。頭長幅指数とその㮖成分子である頭最大 長，顽最大幅の相互関系を図示したものが第 2 図（前揭）である。岩代熱㳙人は中頭型に 属するもの小多く，脰䫓型は少ないことを六 し，加賀山地，加賀辰地人と近く，整城，来

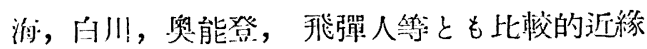

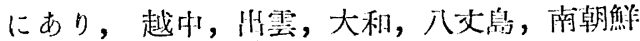
とは比較的遠いことを羊している。

\section{IX 三角形図示による比較}

本均型管，伿篦曲線，指数関係図に より他地方人との比校を試みたか，相 互の関係をより一層明㟲にするために

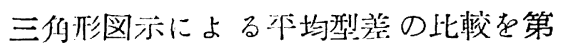
5 図に亦した。但しここに加賀山地， 那賀平地，獘城地方，奥能登のみを対

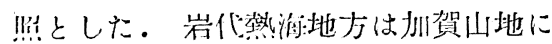
特に近く，次いで加贺平地，盤城地 カ，祭能登の順になるか，これにより

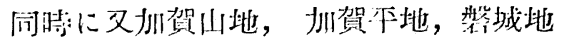
丹，奥能登人の相互の遠近も図示され ている,

\section{要}

約

私、珻和 30 作 4 月休筫 人颣学的

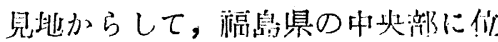
觜多る地方（中通りという。因みに 浜通りとは太平渄海艼湶を云う.)

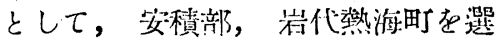
び，その中水に他地方と人稙的に交 流の少ない6 部落の住民 572 名につ

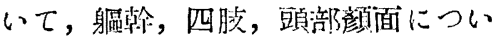
て生体测定を行い, 25 項目の評测值 忍び指数值に基いて詳細な斫究を行 つた。この地方は瞥榒山に接する一 山間峽地であるか，本調查では岩代 被海地地方人と総称した。これを現存 までに詳細に検討されている他地方と比較観 察し，種族的関系を究明し以下の如き結論を 得た。

1. 岩代鯀海地方人は，古屋教授が賞つて 测定された各地方任民に比して身長に於て中 身の部に属する。その平均值は $159.45 \mathrm{~cm}$ て Martin Eの身長分類による中の下に属し， がつちりし体桥のものぶ多い。

2.上肢長は比上肢長による分類中「中
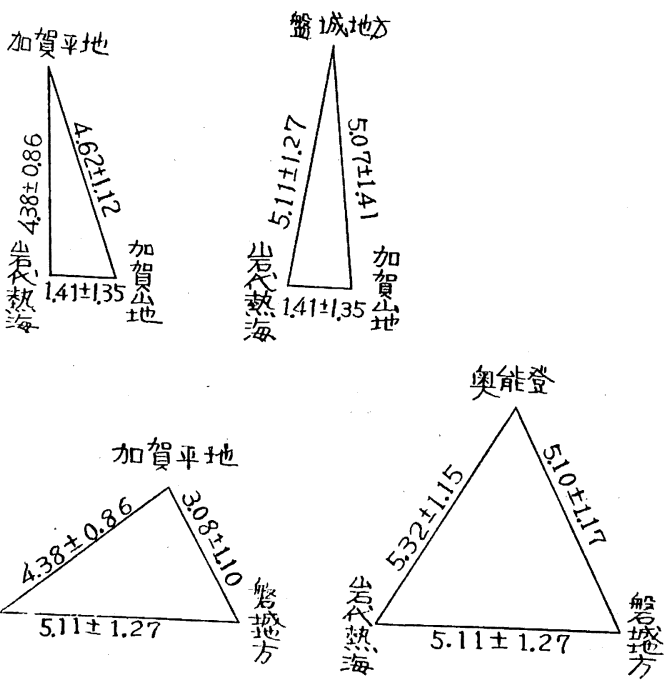

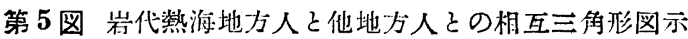


腕」が過斗数を占ひ，全体の傾问は盤城地少 人に橴だよく似ている。

3. 站最大長は $187.43 \mathrm{~mm}$, 䫓最大幅は 15 $0.95 \mathrm{~mm}$ で，その比脊，ななわち頭長幅指数 は80.86である。即ち日木人の平均よりは中 頭の中位にあり，奥能登，飛彈，束㴰，加賀 山地人との親近州:が强い。

4. 颧骨弓幅は平均 $14.26 \mathrm{~mm}$ で奥能登人 に最も近心。

5. 顴骨弓下䪽角幅指数は 78.38 で，顏型 分類によると，日本人としてはもつとも多い 中等型に属している。

6. 形態頝面指数は 86.72 で他地方に比し て中の上の部に属する。止佐, 出雲, 三宅 島，慗城地方人に近い值である。

この指数による顏型の分類では中等型が約 牛数を占め, 次いで狹型が多い。

7. 平均型差により他地方との比較をして 見ると，岩代熱海人は，扣賀山地，土佐，三 宅島, 飛彈, 加賀本地, 東游人と種族約近漞 度を示している。(平均型差 5.0 未満)

8. 平均型差 10.0 以上で種族的近親度に於 て大いなる照隔を示すものとしては大和，信 州飯出, 北海檤フイヌ, 南朝鮮人等である。

\section{総括}

以上の総括するに，体質人類学的に最も価 值の高い諸形質の测定成績，特に他の测度や 指数（顏面や四肢）を合せての綜合観察， 古 なわち平均型差の比較考察によると，岩代熱 游地方住民は，加賀山地，㞦賀平地及び柬澥 地方人と似ており，この意味で「中通り」と して往时，北陸，東海地方と交通があり，国 家経営上ここの地に移住するものがあつたと する同地方の伀說や口碑が或る棌度信賴性か; あることを我らに知らしめると共に，客観的 事実の証明を目的とする体質人類学的観察か;
これを寒付けた結果になつた。㠺に站長幅指 数については, 㞦贺, 能登の阴き長㰯型の民

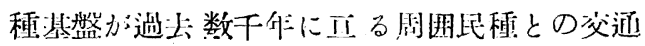
や泥血によつても全くはくすれ允つていない ことは楛だ興味がある。

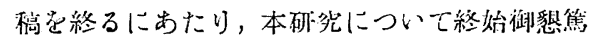

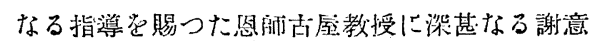

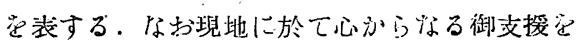
賜つた兟海町長斎藤兵衛，一力舘主小口周三耐 比堂初妙，各部落会長，役堨㛐貝の諸氏に感謝 を擔げる。

\section{參考文 献}

1. Martin: Lehrbuch der Anthronologie, Aufl 2 (1928).

2. 古屋芳雄：医学統計法 (1955).

3. 古屋芳雄 福島県史料等成 (1951).

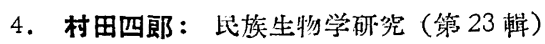
(1937).

5. 古屋芳雉: 同上(笴4. 5.6.7 輯) (1937), (1938), (1939).

6. 熊沢清志: 大和人, 出雲人の体質人瀬学

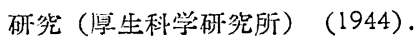

7. 上田栄吉：土佐人 " 十全袺 (1949).

8. 古屋芳雄：日向人” (未発装).

9. 古屋芳雄: Rassenkunde der Aino (1937).

10. 小浜・伊藤：大滒医学專垌学校雑誌 2 , 2 号 (1940).

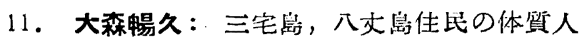
灝学的研究, 日医大誌 17, 6易 (1950).

12. 高野武悅：伊那佳民の体質人䫏学的吥等 倍州医学雑誌 3, 1 㝍 (1954).

13. 湯淺香：北部信州人の " 日医大誌 21, 11 묵 (1954).

14. 村松稳安：暴地为人の " 民族衞生誌 21，5，6旦（1955).

15. 西村義一：福島県磐城地方人の” 日医大誌 22, 2 늫 (1955). 
Regarding the nature of the temporary fall of the blood pressure directly after the sitting-up, the author followed up roentgenologically the change of various measures on the heart sillouette.

It was revealed then, that the change of the sillouette shape occurred in such a way that the stroke volume of the heart corresponded to the maximal blood pressure in their time course during the period following the posture change of the test.

(From the Department of Physiology, University of Tokyo Medical School)

\section{ON THE RESULT OF KRAEPELIN-UCHIDA'S MENTAL WORK TEST, IN WHICH TIME WAS SIGNALED WITH A SIGNAL CLOCK INSTEAD OF BY A SUPERVISOR}

By

Yoshiko Yamanouchi (Miss)

1. Four normal girl students of a provincial Girl's Junior College volunteered and was subjected to repeated tests for the ability of mental work, carried out after the procedure developed by Mr. Yusaburo Uchida.

Of four test-sessions, covering 2 weeks, the first and the third tests were performed with oral signaling, while the second and the fourth tests were done with a signal clock.

2. With oral signaling, initial effort effect was sometimes absent or less marked, which was not the case with clock signaling procedure. No other significant differences were noticed between the two procedures.

3. A "hump" formation was often observed somewhere about the tenth minute from the beginning of the test, in individual curves as well as collective composite curves.

(From the Division of Health Care and Nursing, University of Tokyo and Hiroshima Prefectural Girls' Junior College)

\section{A CONSTITUTIONAL AND ANTHROPOLOGICAL STUDY OF \\ INHABITANTS OF IWASHIRO-ATAMI (Köriyama) DISTRICT, FUKUSHIMA PREFECTURE}

By

\section{Goichiro Miyasaka}

A biometric study was conducted in the central district of Fukushima Prefecture, in April 1955 for the purpose of finding out anthropological chracteristics of inhabitants of the Iwashiro-Atami district. Six villages, relatively isolated from blood mixture with other communities, were chosen and 572 adult males were studied with reference to the 
anthropological measurement of the trunk, limbs, head and face. On the basis of 25 items obtained from the direct measurement and subsequent computation, detailed analyses were made in comparison with other districts where similar survey results were available.

In summary, it was found that the inhabitants of Iwashiro-Atami district showed close resemblance to inhabitants of Kaga and Tókai provinces. It may be interesting to note in this connection, that local traditions of the district often claim the origin of its inhabitants as an ancient political immigration of a race which was closely associated with Hokuriku and Tôkai provinces. Most outstanding was the fact that the length-width index of the head of this district, 8.086, i. e. the long head type was maintained for a few thousand years, notwithstanding the intercourse and blood mixture with other communities.

The present study, it is hoped, will contribute to the formation of a general picture of the genesis of the Japanese race as a whole.

(From the Department of Public Health, Nihon Medical College, Hongo, Tokyo) 